6. Allison AB, Organtini LJ, Zhang S, Hafenstein SL, Holmes EC, Parrish CR. Single mutations in the VP2 300 loop region of the three-fold spike of the carnivore parvovirus capsid can determine host range. J Virol. 2015;90:753-67. https://doi.org/10.1128/JVI.02636-15

7. Allison AB, Kohler DJ, Ortega A, Hoover EA, Grove DM, Holmes EC, et al. Host-specific parvovirus evolution in nature is recapitulated by in vitro adaptation to different carnivore species. PLoS Pathog. 2014;10:e1004475. https://doi.org/10.1371/journal.ppat.1004475

8. Chang YC, Lin ZY, Lin YX, Lin KH, Chan FT, Hsiao ST, et al. Canine parvovirus infections in Taiwanese pangolins (Manis pentadactyla pentadactyla). Vet Pathol. 2021;58:743-50. https://doi.org/10.1177/03009858211002198

Address for correspondence: Ben M. Hause, Department of Veterinary and Biomedical Sciences, South Dakota State University, Box 2175, 1155 North Campus Dr, Brookings, SD 57007, USA; email: benjamin.hause@sdstate.edu

\section{Antenatal Seroprevalence of Zika and Chikungunya Viruses, Kingston Metropolitan Area, Jamaica, 2017-2019}

Joshua J. Anzinger, Chadwic D. Mears, A.E. Ades, Keisha Francis, Yakima Phillips, Ynolde E. Leys, Moira J. Spyer, David Brown, Ana M. Bispo de Filippis, Eleni Nastouli, Thomas Byrne, Heather Bailey, Paulette Palmer, Lenroy Bryan, Karen Webster-Kerr, Carlo Giaquinto, Claire Thorne, Celia D.C. Christie, on behalf of the ZIKAction Consortium ${ }^{1,2}$

Author affiliations: The Global Virus Network Jamaica Affiliate, Kingston, Jamaica (J.J. Anzinger); The University of the West Indies, Kingston (J.J. Anzinger, C.D. Mears, K. Francis, Y. Phillips, Y.E. Leys, P. Palmer, L. Bryan, C.D.C. Christie); University of Bristol, Bristol, UK (A.E. Ades); University College London, London, UK (M.J. Spyer, E. Nastouli, T. Byrne, H. Bailey, C. Thorne); Instituto Oswaldo Cruz, Rio De Janeiro, Brazil (D. Brown, A.M.B. de Filippis); University College London Hospitals NHS Trust, London (E. Nastouli); Ministry of Health, Kingston (K. Webster-Kerr); University of Padova, Padua, Italy (C. Giaquinto)
To determine the extent of exposure to Zika virus (ZIKV) and chikungunya virus (CHIKV) in Jamaica, we collected serum from 584 pregnant women during $2017-2019$. We found that $15.6 \%$ had antibodies against ZIKV and $83.6 \%$ against CHIKV. These results indicate potential recirculation of ZIKV but not CHIKV in the near future.

DOI: https://doi.org/10.3201/eid2802.211849

$\mathrm{T}$ he recent introductions of chikungunya virus (CHIKV) and Zika virus (ZIKV) in the Americas led to widespread epidemics with substantial health and economic effects. Small island developing states in the Caribbean are particularly affected by emerging mosquitoborne disease, primarily because of year-round climatic conditions favorable for mosquito breeding, high levels of poverty, and extensive migration.

In Jamaica, introductions of CHIKV in 2014 and ZIKV in 2016 led to epidemics that overwhelmed the healthcare system $(1,2)$. Despite the Caribbean being greatly affected by the CHIKV and ZIKV epidemics, information regarding the extent of population exposure is limited; most previous studies examined high-resource Caribbean islands. Studies performed after the introduction of CHIKV into the Caribbean showed CHIKV seroprevalence to be Guadeloupe $48.1 \%$ (3), Haiti $78.7 \%$ (4), Martinique $41.9 \%$ (3), Puerto Rico 23.5\% (5), and Saint Martin 16.9\% (6). A serosurvey of participants in rural and urban areas in Suriname in 2017 showed a ZIKV seroprevalence of $35.1 \%$ overall and $24.5 \%$ in a remote village (7); in Martinique in 2016, seroprevalence of blood donors was $42.2 \%(8)$.

To determine seroprevalence in the greater Kingston, St. Andrew, and St. Catherine metropolitan region in Jamaica, we performed a CHIKV IgG and ZIKV IgG serosurvey of 584 pregnant women attending 5 public antenatal clinics in the Kingston Metropolitan Area (KMA) from June 28, 2017, through April 15,2019 . Pregnant women $\geq 16$ years of age attending 1 of the 5 antenatal clinics and planning to deliver at 1 of the $3 \mathrm{KMA}$ public maternity hospitals were eligible for enrollment. The South East Regional Health Authority report of 20,817 total live births at the $3 \mathrm{KMA}$ public maternity hospitals from July 2017 through April 2019 indicates that our study represents $\approx 3 \%$ of

${ }^{1}$ Preliminary results from this study were presented at the 2 nd International Conference on Zika Virus and Aedes Related Infections; June 14-17, 2018; Tallinn, Estonia.

${ }^{2}$ Members of the ZIKAction Consortium are listed at the end of this article. 
pregnant women delivering at a KMA public maternity hospital.

To detect antibodies for each virus, we used the Euroimmun chikungunya virus IgG ELISA (https://www.euroimmun.com) and BLACKBOX Zika virus ELISA (Bernhard-Nocht-Institut für Tropenmedizin, https://www.bnitm.de). Because serologic cross-reactivity with related flaviviruses can be problematic for accurately identifying past ZIKV infections, it is imperative that ZIKV serologic assays account for cross-reactive antibodies. The BLACKBOX Zika virus ELISA is a ZIKV immune complex-binding IgG ELISA that is highly specific and does not show cross-reactivity with dengue virus (DENV) (9). For prevalence estimates, we calculated Clopper-Pearson CIs. This study was approved by the University of the West Indies Ethics (ECP 100 18/19) and Ministry of Health Ethics Committees $(2017 / 06)$.

Among women attending all antenatal clinics, $83.6 \%$ (95\% CI 80.0\%-86.5\%, range $72.2 \%-88.1 \%$ ) were positive for CHIKV IgG (Table), and $15.6 \%$ (95\% CI $12.7 \%-18.8 \%$, range $12.6 \%-22.4 \%$ ) of samples tested were positive for ZIKV (Table). Of the 91 ZIKV IgGpositive women, 72 were also positive for CHIKV IgG, indicating a highly significant odds ratio for the association (21.9, 95\% CI 13.8-36.7), probably resulting at least in part from the 2 viruses being transmitted primarily by Aedes aegypti mosquitoes.

To ensure that the seroprevalence results were not inflated by false positives, we also examined 89 archived serum samples from pregnant women who had attended 1 of the 5 clinics examined (clinic D) during June-December 2013. This period predates CHIKV and ZIKV introductions into Jamaica and was a period of low DENV circulation, similar to 2017-2019 (Ministry of Health Epidemiology Bulletin, https://www.moh.gov). All 89 samples were negative for CHIKV IgG and ZIKV IgG (no results were equivocal), indicating that false-positive results were unlikely to affect the reported CHIKV and ZIKV seroprevalence for 2017-2019.

Our study indicates a high level of past CHIKV infections and a low level of ZIKV exposure among pregnant women in Jamaica receiving antenatal care during 2017-2019. We offer several possible explanations for the higher seroprevalence of CHIKV compared with ZIKV. CHIKV infections result in substantially greater viremia, which could lead to increased transmission rates for CHIKV. In addition to the lower viremia associated with ZIKV, preexisting antibodies to DENV can be cross-protective against ZIKV infection (10), which may have limited transmission in Jamaica. During the 2016 ZIKV epidemic in Jamaica, wide circulation of DENV (Appendix Figure, https://wwwnc.cdc. gov/EID/article/28/2/21-1849-App1.pdf) could have limited ZIKV transmission because of crossreactive antibodies generated during DENV infection or competition between the 2 viruses during cocirculation.

Cases of CHIKV and ZIKV infection in Jamaica have been extremely limited since their initial epidemic years. Only $21 \mathrm{CHIKV}$ cases were reported in Jamaica during 2015-June 2020, and only 1 ZIKV case was reported during 2017-June 2020. CHIKV cases will probably remain limited in Jamaica until a more substantial portion of the population lacks immunity. In contrast, ZIKV could possibly circulate again in Jamaica in the near future because of low population immunity and waning cross-reactive DENV antibodies.

\begin{tabular}{|c|c|c|c|c|}
\hline \multirow[b]{2}{*}{ Virus, clinic } & \multirow[b]{2}{*}{ Tested, no. } & \multicolumn{3}{|c|}{ Result } \\
\hline & & Negative, no. & Equivocal, no. & Positive, no. (\%) \\
\hline \multicolumn{5}{|c|}{ Chikungunya* } \\
\hline A & 54 & 11 & 4 & $39(72.2)$ \\
\hline $\mathrm{B}$ & 159 & 19 & 0 & $140(88.1)$ \\
\hline C & 76 & 8 & 2 & $66(86.8)$ \\
\hline D & 197 & 34 & 5 & $158(80.2)$ \\
\hline $\mathrm{E}$ & 98 & 9 & 4 & $85(86.7)$ \\
\hline Total & 584 & 81 & 15 & $488(83.6)$ \\
\hline \multicolumn{5}{|l|}{ Zikat } \\
\hline A & 54 & 44 & 0 & 10 (18.5) \\
\hline B & 159 & 138 & 1 & $20(12.6)$ \\
\hline C & 76 & 64 & 1 & $11(14.5)$ \\
\hline D & 197 & 166 & 3 & $28(14.2)$ \\
\hline $\mathrm{E}$ & 98 & 75 & 1 & $22(22.4)$ \\
\hline Total & 584 & 487 & 6 & $91(15.6)$ \\
\hline
\end{tabular}

*Euroimmun CHIKV IgG ELISA (https://www.euroimmun.com).

†BLACKBOX ZIKV IgG ELISA (https://www.bnitm.de). 
Members of the ZIKAction Consortium: A.E. Ades, Joshua J. Anzinger, Heather Bailey, Brittiana Brown, David Brown, Thomas Byrne, Leroy Campbell, C.D.C. Christie, Ana M. Bispo de Filippis, Carla Giaquinto, Georgiana Gordon-Strachan, Marlyn Grindley, Donna Kamicka, Clayton Kelly, John Lindo, Paul Mitchell, Orville Morgan, Eleni Nastouli, Alexander Onyonyor, Paulette Palmer, Russell Pierre, Amanda Rousseau, Sofier Scott, Claire Thorne, and Karen Webster-Kerr.

\section{Acknowledgments}

We thank the women who participated in this study, research nurses, pediatricians, medical technologists, and the ZIKAction Project Management team (Francesca Viero and Giorgia Dalla Valle).

As Global Infectious Diseases Scholars, C.M. and Y.L. received mentored research training in the development of this manuscript. This training was supported in part by the University of Buffalo Clinical and Translational Science Institute award UL1TR001412 and the Global Infectious Diseases Research Training Program award D43TW010919.

This project was funded from the Horizon 2020: EU Programme for Research and Innovation under grant agreement no. 734857 .

\section{About the Author}

Dr. Anzinger is a senior lecturer and director of the Global Virus Network Jamaica Affiliate at the University of the West Indies and is a consultant virologist and head of the virology laboratory at the University Hospital of the West Indies. His research primarily focuses on comorbid disease during chronic HIV infection and emerging mosquitoborne viruses.

\section{References}

1. Duncan J, Gordon-Johnson KA, Tulloch-Reid MK, Cunningham-Myrie C, Ernst K, McMorris N, et al. Chikungunya: important lessons from the Jamaican experience. Rev Panam Salud Publica. 2017;41:e60. https:/ / doi.org/10.26633/RPSP.2017.60

2. Webster-Kerr KR, Christie C, Grant A, Chin D, Burrowes H, Clarke K, et al. Emergence of Zika virus epidemic and the national response in Jamaica. West Indian Med J. 2016; 65:243-9.

3. Gallian P, Leparc-Goffart I, Richard P, Maire F, Flusin O, Djoudi R, et al. Epidemiology of chikungunya virus outbreaks in Guadeloupe and Martinique, 2014: an observational study in volunteer blood donors. PLoS Negl Trop Dis. 2017;11:e0005254. https:// doi.org/10.1371/ journal.pntd.0005254

4. Poirier MJ, Moss DM, Feeser KR, Streit TG, Chang G-JJ, Whitney M, et al. Measuring Haitian children's exposure to chikungunya, dengue and malaria. Bull World Health Organ. 2016;94:817-825A.
5. Simmons G, Brès V, Lu K, Liss NM, Brambilla DJ, Ryff KR, et al. High incidence of chikungunya virus and frequency of viremic blood donations during epidemic, Puerto Rico, USA, 2014. Emerg Infect Dis. 2016;22:1221-8. https:// doi.org/ 10.3201/eid2207.160116

6. Gay N, Rousset D, Huc P, Matheus S, Ledrans M, Rosine J, et al. Seroprevalence of Asian lineage chikungunyua virus infection on Saint Martin Island, 7 months after the 2013 emergence. Am J Trop Med Hyg. 2016;94:393-6. https:/ / doi.org/10.4269/ajtmh.15-0308

7. Langerak T, Brinkman T, Mumtaz N, Arron G, Hermelijn S, Baldewsingh $G$, et al. Zika virus seroprevalence in urban and rural areas of Suriname, 2017. J Infect Dis. 2019;220:28-31. https://doi.org/10.1093/infdis/jiz063

8. Gallian P, Cabié A, Richard P, Paturel L, Charrel RN, Pastorino B, et al. Zika virus in asymptomatic blood donors in Martinique. Blood. 2017;129:263-6. https:/ / doi.org/ 10.1182/blood-2016-09-737981

9. Ehmen C, Medialdea-Carrera R, Brown D, Bispo de Filippis AM, de Sequeira PC, Nogueira RMR, et al. Accurate detection of Zika virus IgG using a novel immune complex binding ELISA. Trop Med Int Health. 2020.

10. Rodriguez-Barraquer I, Costa F, Nascimento EJM, Nery N, Castanha PMS, Sacramento GA, et al. Impact of preexisting dengue immunity on Zika virus emergence in a dengue endemic region. Science. 2019;363:607-10. https:// doi.org/ $10.1126 /$ science.aav6618

Address for correspondence: Joshua J. Anzinger, Department of Microbiology, The University of the West Indies, Kingston, Jamaica; email: joshua.anzinger@uwimona.edu.jm

\section{Group IV Getah Virus in Culex Mosquitoes, Malaysia}

\author{
Sing-Sin Sam, Noor-Adila Mohamed-Romai-Noor, \\ Boon-Teong Teoh, Zur-Raiha Hamim, Hoi-Ying Ng, \\ Juraina Abd-Jamil, Chee-Sieng Khor, \\ Sharifah-Syed Hassan, Hamdan Ahmad, \\ Sazaly AbuBakar
}

Author affiliations: Universiti Malaya, Kuala Lumpur, Malaysia (S.-S. Sam, N.-A. Mohamed-Romai-Noor, B.-T. Teoh, Z.-R. Hamim, H.-Y. Ng, J. Abd-Jamil, C.-S. Khor, S. AbuBakar); Monash University Malaysia, Selangor, Malaysia (S.-S. Hassan); Universiti Sains Malaysia, Pulau Pinang, Malaysia (H. Ahmad)

DOI: https://doi.org/10.3201/eid2802.204887 